Jurnal Unifikasi, ISSN 2354-5976

Vol. 3 No. 2 Juli 2016

\title{
STUDI KOMPARATIF TENTANG ASPEK ONTOLOGI PEMBAGIAN WARIS MENURUT HUKUM ISLAM DAN HUKUM ADAT JAWA
}

\author{
Moh. Zeinudin \\ Fakultas Hukum Universitas Wiraraja, azkazein11@gmail.com \\ Fikri \\ Sekolah Tinggi Agama Islam Miftahul Ulum Tarate Sumenep, nizami.fikri@ gmail.com
}

\begin{abstract}
In the socio-anthropological study, Islam embraced by the indigenous people of Java were quite influential in many aspects of their lives. Even in reality, has always found a dialogical relationship between Islamic law and customary law Java. In connection of that, this article attempts to examine and analyze the similarities and differences on aspects of ontology division of inheritance according to Islamic law and customary law Java. Despite these similarities, especially in the type and status of the estate but it also found differences in the using and distribution of the estate, class of heirs, as well as part of the child.
\end{abstract}

Key Word: ontology, the division of inheritance, islamic inheritance law, customary law Java.

\begin{abstract}
Abstrak
Dalam telaah sosio-antropologis, agama Islam yang dianut oleh masyarakat Jawa ternyata cukup berpengaruh dalam berbagai aspek kehidupan mereka. Bahkan dalam realitas, selalu ditemukan hubungan yang dialogis antara hukum Islam dan hukum adat Jawa. Dalam kaitannya dengan hal tersebut, artikel ini mencoba untuk mengkaji dan menganalisis persamaan dan perbedaan tentang aspek ontologi pembagian waris menurut hukum Islam dan hukum adat Jawa. Walaupun terjadi kesamaan terutama dalam jenis dan status harta warisan, tetapi ternyata juga ditemukan perbedaan dalam hal pemanfaatan dan pembagian harta waris, golongan ahli waris, serta bagian anak.
\end{abstract}

Kata Kunci: ontologi, pembagian waris, hukum waris Islam, hukum adat Jawa.

\section{A. Pendahuluan}

Bangsa indonesia merupakan suatu bangsa yang terdiri dari berbagai suku bangsa. Misalnya di Sumatera ada suku Akit, Minangkabau, dan Batak sedangkan di Sulawesi ada suku Buton, Bugis, atau Makasar. Di Papua ada suku Kapauku, Asmat, atau Amungme dan di Jawa ada suku
Madura, Osing, Badui, Tengger, dan Jawa. Keanekaragaman suku bangsa atau kelompok etnik jumlahnya ratusan sehingga kebudayaan dan hukum adatnya dapat berbeda satu sama lainnya. Perbedaan ini menunjukkan bahwa setiap kelompok masyarakat memiliki ciri khas sebagai identitas suku bangsa yang bersangkutan. 
Ciri khas ini dapat disebut sebagai local genius dan local prudential atau kearifan lokal. Konsep keanekaragaman tersebut oleh Mpu Tantular disebut Bhinneka tunggal ika. ${ }^{1}$

Di samping itu, dalam masyarakat manapun agama yang dianut cenderung berpengaruh dalam berbagai aspek kehidupannya sehingga wajar jika hukum Islam sulit dinafikan eksistensinya di kalangan masyarakat Jawa. Oleh karena itu , bagi suku Jawa berjalannya pluralisme hukum antara hukum Islam dan adat sulit dihindari, bahkan pluralisme ini sudah merupakan hal yang diyakini secara umum (taken for granted). Dalam kaitan ini, Sudaryanto menyatakan bahwa dualisme sulit dihindari karena dalam kenyataannya sebelum mengenal ajaran Islam, masyarakat yang saat ini menganut agama Islam sudah terbiasa diatur dengan norma hukum adat. ${ }^{2}$ Dengan demikian, tarik menarik atau pengaruh-mempengaruhi antara hukum Islam dan adat dalam bidang kewarisan juga sulit dielakkan dalam kehidupan masyarakat Jawa.

Hukum kewarisan adalah himpunan aturan hukum yang mengatur tentang siapa ahli waris yang berhak mewarisi harta peninggalan pewaris. Pada prinsipnya, menurut hukum Islam pewarisan terjadi didahului dengan adanya kematian. Kemudian, orang yang meninggal tersebut meninggalkan harta warisan yang akan

1 Dominikus Rato,2009, pengantar Hukum Adat. LaksBang Pressindo. Yogyakarta. Hal. 3.

2 Agus Sudaryanto, 2005, “ Sepikul Segendong: Harmonisasi Hukum Adat dan Islam dalam Pewarisan terhadap Anak". Dalam Atik Triratnawati dan Mutiah Amini (Eds). Ekspresi Islam dalam Simbol-simbol Budaya di Indonesia. PT. Adicita,Yogyakarta, hal. 225. dibagikan kepada ahli warisnya. Berbeda dengan prinsip dalam hukum adat, prosedur pewarisan tidak selalu didahului adanya kematian. Tanpa kematian pun pewarisan dapat terjadi. Namun demikian, pembagian warisan dalam hukum Islam dan hukum adat dapat berjalan beriringan seperti prinsip pembagian sepikul segendong.

Mengenai aturan hukum yang mengatur kewarisan, negara Indonesia belum mempunyai hukum waris nasional. Suparman dalam kaitan ini menegaskan hukum waris yang berlaku di Indonesia sampai saat ini belum dapat diwujudkan dalam unifikasi hukum. Oleh karenannya, sampai sekarang masih belum terdapat keseragaman pengaturan masalah warisan. ${ }^{3}$ Tidak mudahnya upaya unifikasi hukum dalam bidang kewarisan ini dikerenakan banyaknya halangan yang ditemui, yaitu komplikasi kultural, keagamaan, dan sosiologi ${ }^{4}$. Namun setidaknya terdapat tiga kaidah hukum positif di Indonesia yang mengatur perihal kewarisan, yakni hukum adat, hukum perdata barat dan hukum Islam.

Sebagaimana diketahui, suku Jawa dikenal memiliki budaya adiluhung yang tidak hanya menyentuh bidang politik pemerintahan, religi, tradisi, dan kesenian, tetapi juga meluas ke segala aspek kehidupan. Suku Jawa merupakan salah satu kelompok etnik yang cukup besar jumlahnya di Indonesia. Bahkan diprediksikan suku Jawa menyusun kurang lebih 40\% (empat

3 Eman Suparman, 2005, Hukum Waris Indonesia dalam Perspektif Islam, Adat dan BW. PT.Refika Aditama, Bandung, hal. 5.

${ }^{4}$ Mochtar Kusumaatmadja, 1975, Pembinaan Hukum dalam Rangka Pembagunan Nasional, Binacipta. Bandung, hal. 12. 
puluh peresen) jumlah penduduk di Indonesia.

Dalam kaitannya dengan agama, lebih dari $85 \%$ (delapan puluh lima persen) penduduk di Indonesia beragama Islam. Namun, dengan jumlah pemeluk agama Islam yang begitu besar, tidak semua umatnya dapat dijalankan kewajiban agama secara sungguh-sungguh. Perbedaan dalam praktik agama ini sudah menjadi bagian kehidupan di kalangan masyarakat Jawa sejak munculnya Islam ${ }^{5}$. Hal ini dikarenakan secara sosiologis dan kultural hukum Islam memiliki fleksibilitas dan elastisitas. Artinya meskipun ada kekuatan otonom yang terkandung dalam ketetapan Tuhan, tetapi dalam realisasinya hukum Islam mampu melakukan upaya transformative adaptive. ${ }^{6}$ Dalam hal ini tetntunya terdapat beberapa persamaan dan perbedaan di antara ketiga kaidah hukum yang mengatur perihal kewarisan tersebut.

Hukum Islam mengatur beberapa bidang hukum. Posisi hukum kewarisan dalam hukum Islam termasuk dalam lingkup bidang hukum kekeluargaan. Pada umumnya, hukum kekeluargaan diatur dalam Al-Qur'an Surat An-Nisa. Harta peninggalan yang ditinggalkan pewaris tidak serta merta seluruhnya merupakan harta kekayaan yang nantinya akan dibagi kepada segenap ahli waris. Ada suatu saat dimana pewaris meninggalkan harta peninggalan berupa utang. Perihal mengenai mewarisi utang ini sangat penting untuk diperhatikan mengingat bahwa di dalam setiap ketentuan

\footnotetext{
${ }^{5}$ Niels Mulder, 2001, Mistisisme Jawa Ideologi di Indonesia, LkiS Yogyakarta, hlm. 16

6 Sirajuddin, 2008, Legalitas Hukum Islam di Indonesia, Pustaka Pelajar, Yogyakarta, halm. 14.
}

hukum positif yang mengatur perihal kewarisan dalam Alquran maupun Kompilasi Hukum Islam (KHI) selalu disebutkan bahwa bagian harta warisan akan siap untuk dibagi kepada segenap ahli waris jika telah dikurangi dengan utang-utang dan wasiat.

Ketentuan mengenai bagian para ahli waris dalam hukum adat sangat fleksibel karena prinsipnya tidak mengenal bagian mutlak (legitime portie). Hukum adat lebih mementingkan perhatiannya pada jenis harta dan kepentingan ahli waris. Hak untuk mewaris anak laki-laki maupun perempuan pada dasarnya adalah sama. Namun tidak berarti bahwa tiap-tiap anak mempunyai bagian yang sama menurut jumlah angka; melainkan berdasarkan kebutuhan dan kepatutan. Di lain sisi, hukum kewarisan Islam juga mengatur hal yang sama pula masalah hak bagian anak. Oleh karena itu, berdasarkan berbagai hal yang diuraikan di muka, melalui makalah ini penulis berusaha membahas mengenai Aspek Ontologi Pembagian Waris dalam Hukum Islam dan Hukum Adat Jawa.

Berdasarkan latar belakang sebagai mana telah dijabarkan di atas, maka dalam kajian ini difokuskan pada rumusan masalah pembagian sebagai berikut:

1. Bagaimana prinsip pambagian waris menurut hukum Islam maupun hukum adat di kalangan masyarakat Jawa?

2. Apa saja aspek ontologi yang terkandung pada pembagian waris yang ditentukan dalam hukum adat Jawa maupun hukum Islam tersebut?

\footnotetext{
7 Tamakiran S, 2000, Asas-asas Hukum Waris Menurut Tiga Sistem Huku, Pionir Jaya, Bandung, halm. 71.
} 


\section{B. Pembagian Waris dalam Hukum Islam dan Adat Jawa}

Banyak aspek yang dpat dijadikan fokus kajian dalam masalah pembagian waris. Namun, tulisan ini hanya akan membahas hal-hal yang berkaitan dengan aspek harta warisan, saat pewarisan, golongan ahli waris, dan pembagian warisan anak. Walaupun pembahasan masalah ini belum dapat menjawab permasalahan secara komprehensif atau sempurna, tetapi setidaknya pembahasan ini dapat memberikan gambaran secara sepintas tentang beberapa aspek bidang waris dalam hukum adat maupun Islam.

Kajian berkaitan antara hukum adat dan Islam dalam bidang waris sudah tidak asing lagi karena sudah lama selalu menjadi perhatian bagi para ahli. Hal ini terbukti dengan munculnya berbagai teori dan idiom atau maksim yang eksis dalam kehidupan berbangsa di negara Indonesia. Sebagai contoh kita mengenal teori receptio in complexu, receptie, receptie exit, maupun receptio a contrario. Lalu masyarakat Minangkabau memiliki maksim adat basandi syarak, syarak basandi kitabullah (adat berdasarkan syariah, syariah berdasarkan Al-Qur'an). Masyarakat Aceh mengatakan hukum ngon adat hantom cre, lagee zat ngon sifeun (hukum Islam dan adat tidak terpisahkan, seperti layaknya zat dan sifat dari suatu benda). Di Ambon masyarakat sering mengatakan adat dibikin di masjid ${ }^{8}$.

Menurut Endaswara, di dalam tradisi Jawa agama dan adat tercampur karena

\footnotetext{
8 Ratno Lukito, 2008, Tradisi Hukum Indonesia. Teras, Yogyakarta, hlm. 65.
}

terjadi sinkretisme. Di Jawa, keterkaitan ini dikenal dengan istilah 'Islam Jawa', karena sinkretisme antara Islam dan tradisi (adat) memunculkan tradisi yang disebut kejawen? ${ }^{9}$. Kondisi menunjukkan bahwa di Jawa, adat dan agama tidaklah jauh berbeda, bahkan kadangkala sulit dipilih dan dipisah karena seakan-akan telah menyatu. Bahkan dalam masalah hukum waris adat pun sulit dimungkiri munculnya kompromi dengan hukum Islam. Terkadang, prinsip pewarisan hukum Islam dan adat bahkan kebetulan sama, seperti pembagian sepikul segendong, yaitu pembagian waris 2 berbanding 1 . Namun, diperlukan kajian yang lebih intens terhadap masalah ini masih untuk menyakinkan bahwa prinsip segendong sepikul itu sudah ada sebelum Islam dipeluk oleh orang Jawa atau setelah Islam berkembang di Jawa. Seperti maksim sangkan paraning dumadi, manunggaling kawula gusti atau memayu hayuning bawana ${ }^{10}$.

\section{Harta Warisan}

Dalam perspektif Islam, harta warisan merupakan jumlah total harta bawaan dan harta bersama setelah dikurangi untuk keperluan pewaris selama sakit, biaya pengurusan jenazah, pembayaran utang, serta wasiat pewaris ${ }^{11}$. Menurut Anshori, jika dilihat dari aspek jenjangnya harta dalam perkawinan dapat digolongkan

\footnotetext{
9 Suwardi Endaswara, 2006, Falsafah Hidup Jawa, Cakrawala, Yogyakarta, hlm. 77.

10 Suwardi Endaswara, 2006, Mistik Kejawen Sinkritisme, Simbolisme dan Sufisme dalam Budaya Spiritual Jawa, Narasi, Yogyakarta, hlm. 75 dan hlm. 83.

${ }^{11}$ Zainuddin Ali, 2008, Pelaksanaan Hukum waris di Indonesia, Sinar Grafika, Jakarta, hlm. 46-47
} 
menjadi 3 (tiga) macam, yaitu harta kekayaan, peninggalan, dan warisan. Harta kekayaan adalah seluruh harta yang dimiliki oleh seseorang secara pribadi dan atau secara bersama-sama ketika masih hidup. Harta peninggalan adalah seluruh harta benda yang ditinggalkan oleh orang yang meninggal dunia dan menjadi hak ahli waris. Adapun harta warisan merupakan harta sisa setelah diambil untuk berbagai kepentingan seperti biaya perawatan, pengeburan jenazah, pelunasan utang, dan penunaian wasiat $^{12}$.

Syarifuddin menatakan harta warisan menurut hukum Islam adalah segala sesuatu yang ditinggalkan pewaris yang secara hukum dapat beralih kepada ahli waris. Bentuk harta warisan yang lazim ialah berupa benda, baik bergerak maupun tidak bergerak . lebih lanjut ditegaskan, harta peninggalan merupakan apa-apa yang ditinggalkan oleh pewaris saat kematiannya, sedangkan harta warisan adalah harta yang berhak diterima dan dimiliki oleh ahli waris. Masalah yang berkaitan dengan utang dari yang meninggal dunia tidak dapat diwariskan. Oleh karena iu, bukanlah merupakan kewajiban ahli waris untuk melunasi utang si pewaris dengan harta pribadinya. ${ }^{13}$ Dalam Pasal 171 huruf e Komplikasi Hukum Islam ditegaskan sebagai berikut:

12 Abdul Ghofur Anshori, 2002, Hukum Kewarisan Islam di Indonesia Eksistensi dan Adaptabilitas, Ekonesia Fakultas Ekonomi UII, Yogyakarta, hlm. 164.

13 Amir Syarifuddin, 1984, Pelaksanaan Hukum Kewarisan Islam dalam Lingkungan Adat Minangkabau, PT.Gunung Agung, Jakarta, hlm. 5356.
Harta warisan adalah harta bawaan ditambah bagian dari harta bersama setelah digunakan untuk keperlua pewaris selama sakit sampai meninggalnya, biaya pengurusan jenazah (tajhiz), pembayaran hutang, dan pemberian untuk kerabat.

Dengan demikian, berdasarkan berabagai pendapat dan berdasarkan aturan KHI di atas,dapat dinyatakan bahwa harta benda yang ditinggalkan sebelum diambil untuk memenuhi berbagai kepentingan pewaris tersebut disebut sebagai harta peninggalan bukan harta warisan. Suatu harta benda berstatus harta warisan jika sudah melewati pemenuhan berbagai kewajiban yang harus dijalankan untuk kepentingan pewaris.

Menurut hukum adat Jawa, semua harta baik yang berstatus sebagai harta asal (gawan) dan harta bersama (gana gini) yang dikuasai selama perkawinan. ${ }^{14}$ Sedangkan harta peninggalan adalah suatu harta warisan yang belum terbagi atau tidak dapat dibagi dikarenakan salah seorang pewaris masih hidup. Harta warisan merupakan harta kekayaan dari pewaris yang telah wafat, baik harta itu telah terbagi atau masih dalam keadaan tidak terbagi. ${ }^{15}$ Walaupun menurut hukum adat harta warisan bukan merupakan kesatuan sperti menurut hukum Islam, tetapi harta warisan tetap merupakan harta yang telah dibersihkan dari utang-piutang. Hadikusuma menyatakan bahwa yang layak diperhitungkan untuk menyelesaikan utangpiutang hanyalah harta bersama sedangkan

14 R. Otje Salman, 2007, Kesadaran Hukum Masyarakat terhadap Hukum Waris, PT. Alumni, Bandung, hlm. 54.

${ }^{15}$ Hilman Hadikusuma, 1999, Hukum Waris Adat, PT. Citra Aditya Bakti, Bandung, hlm. 11 
harta asal atau harta bawaan yang ada kaitannya dengan kekerabatan tidak patut diperhitungkan. ${ }^{16}$ Kepemilikan atas harta warisan masih dipengaruhi oleh sifat-sifat kurukan dan kebersamaan sehingga rasa persatuan dan persaudaraan masih sangat berpengaruh dalam pergaulan hidup suatu keluarga. Namun, dalam perkembangannya, sulit pula dihindari munculnya fenomena keluarga-keluarga yang sudah tidak begitu peduli dengan masalah seperti itu. Akan tetapi cara berfikir dan sikap individual yang sangat mengutamakan kepentingan kebendaan bukanlah kepribadian suku Jawa yang asli.

Harta warisan baik menurut hukum Islam dan hukum adat Jawa secara global terdiri dari dua jenis harta yaitu harta asal maupun harta bersama. Pada umumnya untuk dapat disebut sebagai harta warisan. Maka harta yang bersangkutan harus sudah dibersihkan dari berbagai kepentingan si pewaris. Perbedaannya dalam hukum Islam, semua harta warisan baik yang berasal dari harta asal maupun harta bersama dapat dipertenggungjawabkan untuk melunasi kepentingan pewaris. Namun menurut hukum adat harta warisan yang dapat dipertanggungjawaban terhadap kepentingan pewaris hanyalah untuk jenis harta bersama atau gana gini.

\section{Saat Pewarisan}

Setiap manusia tidak dapat menghindari kematian karena Allah sudah menetapkan bahwa semua makhluk pasti mati. Manusia merupakan salah satu makhluk ciptaan Allah sehingga kepastian kematian bagi manusia

\footnotetext{
${ }^{16}$ Ibid, hlm.65.
}

tidak dapat ditampilkan dalam kehidupannya. Peristiwa kematian dapat dipastikan akan menimbulkan kewarisan. Oleh karena itu masalah kewarisan itu timbul setelah adanya kematian pewaris, Pasal 171 huruf b KHI menegaskan bahwa jika idak ada kematian maka tidaka ada kewarisan. Dengan demikian dapat dikatakan bahwa dalam hukum Islam proses pewarisan hanya dapat terjadi setelah pewaris meninggal dunia.

Salman dan Haffas menegaskan bahwa matinya pewaris mutlak harus dipenuhi untuk adanya pewarisan. Jika seorang memberikan harta kepada para ahli waris ketika pewaris masih hidup, maka itu bukan pewarisan. ${ }^{17}$ Masalah pembagian harta warisan di antara para ahli waris menurut Islam merupakan sesuatu yang harus segera dilakukan setelah kewajiban ahli waris terhadap pewaris ditunaikan. Seperti pemakaman jenazah, menyelesaikan utangpiutang, atau menjalankan wasiat pewaris. ${ }^{18}$ Hal ini dikarenakan jika pembagian waris ditunda-tunda, maka sangat dimungkinkan dikemudian hari akan timbul berbagai masalah yang berkaitan dengan harta warisan. Oleh karena itu, dalam pembagian wris Islam mengajarkan lebih cepat lebih baik (the sooner the better).

Dalam hukum waris adat saat atau proses pewarisan dapat berjalan sebelum pewaris meninggal dunia dan/atau setelah pewaris meninggal dunia. Proses pewarisan ketika pewaris masih hidup dapat terjadi dengan beberapa cara, yaitu penerusan atau

\footnotetext{
${ }^{17}$ R. Otje Salman dan Mostofa Haffas, 2006, Hukum Waris Islam. PT. Refika Aditama, Bandung, hlm. 5.

${ }^{18}$ Mukti Arto, 2009, Hukum Waris Bilateral dalam Komplikasi Hukum Islam, Balqis Queen. Solo, hlm. 1006-107.
} 
pengalihan (Jawa litiran), penunjukan (acungan), dan mewasiatkan atau berpesan (weling atau wekas). Pada umumnya, pewarsan dilakukan sebelum pewaris meninggal dunia karena pewaris melakukan pengalihan atau penunjukan saat ia berumur lanjut dan anak-anaknya sudah mantap berumahtangga. Harta kekayaan pewaris yang diberikan kepada ahli waris dimaksudkan sebagai bekal kebendaan dalam mendirikan atau memperkokoh kehidupan rumah tangga anak. Dalam prinsip orang Jawa dikatakan orang lelaki membuat rumah sedangkan orang perempuan yang megisinya (wong lanang ngomahi wong wadon ngiseni). Pesan atau wasiat dari orang tua kepada para waris ketika masih hidup biasanya diucapkan secara terang dan disaksikan oleh para waris. Anggota keluarga, tetangga atau tua-tua desa.

Setelah pewaris meninggal dunia, proses pewarisan terjasi melalui cara penugasan atau pembagian. Penguasaan atas harta warisan dilakuakn jika harta warisan tersebut tidak dibagi atau karena pembagiannya diunda dengan berbagai alasan seperti pewaris tidak mempunyai keturunan, ahli waris belum dewasa, atau adanya utang-piutang yang belum diselesaikan. Apabila harta warisan akan dibagi, maka hal yang perlu diperhatikan adalah masalah menentukan waktu yang baik untuk dilakukan pemabagian warisan. Walaupun waktu dilakukannya pembagian warisan tidak ditentukan dengan pasti, tetapi pada umumnya waktu pembagian warisan tidak ditentukan dengan pasti, tetapi pada umunya waktu pembagian warisan dijalankan setelah upacara sedekah atau selamatan pewarisan. Hal ini dikerenakan pada waktu tersebut dapat dipastikan para ahli waris dapat berkumpul.

Dalam masalah waktu pembagian warisan, terdapat perbedaan antara hukum Islam dan hukum adat. Dalam hukum Islam, pembagian warisan hanya dapat berlangsung setelah terjadinya kematian sedangkan menurut hukum adat tidak harus demikian karena pembagian warisan dapat berlangsung saat pewaris masih hidup maupun setelah pewaris meninggal dunia. Maslah pembagian waris saat pewaris masih hidup atau setelah meninggal sangat ditentukan oleh situasi dan kondisi masingmasing keluarga.

\section{Ahli Waris}

Azhar Basyir menyatakan bahwa ahli waris dapat digolongkan menjadi tiga berdasarkan dari segi hak mereka atas hara warisan, yaitu ahli waris dzawil furudl, ashabah dan dzawil arham. Dzawil furudl merupakan golongan ahli waris yang bagian haknya tertentu, yaitu 2/3.1/2, 1/3, 1/4, 1/6 dan 1/8. Ashabah adalah golongan ahli waris yang bagian haknya tidak tertentu tetapi akan menerima seluruh harta warisan jika tidak ada ahli waris dzawil furudl. Apabila ada ahli waris dzawil furudl, maka ahli waris ashabah hanya berhak atas harta yang tersisa dan jika ternyata tidak ada sisa harta sama sekali, maka ahli waris ashabah tidak mendapatkan bagian apapun. Adapun Dzawil arham merupakan golongan ahli waris yang hanya atas harta warisan disebabkan oleh hubungan kerabat dengan pewaris. Dzawil arham tetapi tidak termasuk golongan dzhawil furudldan 
ashabah. ${ }^{19}$ Dalam perspektif lain, Tutik menyatakan bahwa menurut Islam ahli waris dapat digolongkan menjadi dua, yaitu ahli waris nasabiyah karena hubungan kewarisannya dikerenakan adanya suatu sebab seperti pernikahan, agama atau perjanjian $^{20}$. Menurut hukum Islam, jika semua golongan yang berhak sebagai ahli waris (baik ahli waris yang tergolong nasabiyah maupun sabbiyah) hadir, maka yang berhak mendapat harta warisan adalah suami atau isteri, ibu dan ayah, serta anak lelaki dan perempuan ${ }^{21}$. Degan demikian, apabila dibandingkan dengan hukum adat, maka hukum Islam lebih cenderung membagikan harta warisan kepada sebanyak mungkin ahli waris ${ }^{22}$ karena ahli waris anak tidak manutup hak ahli waris yang lain, yaitu janda atau duda, ibu dan ayah.

Pada umunya, ahli waris di masyarakat Jawa merupakan seorang atau beberapa orang yang berhak menerima harta warisan dari pewaris. Menurut prinsip hukum adat, ahli waris yang utama dan pertama dari pemilik harta kekayaan adalah anak. Dengan demikain, dalam wari me-warisi hukum adat sangat mengutamakan hubungan darah. Di samping itu, ada pula prinsip saling menutup bagi kelompok ahli waris satu terhadap hak waris kelompok lainnya. Sebagai contoh, jika ahli waris anak hadir, maka secara

19 Ahmad Azhar Basyir, 1982, Hukum Waris Islam, Fakultas Ekonomi UII, Yogyakarta, hlm. 24-27.

20 Titik Triwulan Tutik, 2006, Pengantar Hukum Perdata di Indonesia, prestasi Pustaka Publiser, Jakarta,hlm.319.

${ }^{21}$ Syamsul Rijal Hamid, 2000, Buku Pintar Agama Islam, Penerbar Salam, Jakarta, hlm. 272.

22 Abdul Ghofur Anshori dan Yulkanain Harahab, 2008, Hukum Islam Dinamika dan Perkembangannya di Indonesia, Kreasi Total Media, Yogyakarta. Hlm. 226. otomatis ahli waris lain tidak berhak menjadi ahli waris karena tertutup oleh ahli waris yang lebih utama. Menurut Sudiyat, dalam hukum adat Jawa para ahli waris dapat dikelompokkan dalam tata urutan utama sebagai berikut:

1. Keturunan pewaris;

2. Orangtua pewaris;

3. Saudara-saudara pewaris atau keturunannya; dan

4. Orangtua dari orang tua pewaris atau keturunannya ${ }^{23}$.

Dalam pengelompokan, janda, duda, dan anak angkat tidak dimasukkan ke dalam ahli waris karena ada pendapat bahwa mereka bukanlah ahli waris meskipun dalam perkembangannya mereka mendapatkan bagian dari harta warisan.

Dengan demikian, sulit dihindari adanya beberapa perbedaan antara hukum Islam dan hukum adat Jawa dalam masalah ahli wris. Dalam hukum Islam ahli waris ditentukan berdasarkan hubungan nasah dan perkawinan sementara hukum adat lebih mengutamakan adanya hubungan nasab. Di samping itu, pembagian waris Islam cenderung meluas atau merangkul sebanyak mungkin ahli waris sedangkan pembagian waris menurut hukum adat cenderung lebih limitatif karena adanya prinsip saling menutup antara para pihak yang potensial sebagai ahli waris.

\section{Bagian Anak}

Dalam perspektif hukum Islam, hukum waris mempunyai kedudukan yang sangat penting dan diatur secara jelas rinci karena

23 Imam Sudiyat, 1983, "Peta Hukum Waris di Indonesia", Simposium Hukum Waris Nasional, Jakarta, hlm. 25. 
masalah pewarisan pasti di alami setiap orang. Selain itu, hukum waris dapat dipastikan akan bersangkutan dengan maslah harta benda. Dengan demikian, jika tidak diatur secara tegas dan jelas, sengketa harta di antara para ahli waris setelah kematian pewaris sangat potensial timbul. Oleh karena itu, hukum waris Islam membedakan besar kecil bagian para ahli waris yang disesuaikan dengan kebutuhan hidup sehari-hari. Bagian-bagian tertentu bagi para ahli waris yang sudah ditentukan tersebut termasuk hal yang sifatnya ta'abbudi yang wajib dilaksanakan oleh sebab menjadi ketetapan sebagaimana dinyatakan dalam Alquran surat An-Nissa ayat 11,12 , dan 13 . Jika kita cermati, pengaturan dalam ayat tersebut sangat tegas. Dapat kita lihat bagaimana Alquran menggunakan ungkapan yushikumullah (Allah mewasiatkan), faridhatan min Allah (kewajiban dari Allah), washiyatan min Allah (wasiat dari Allah), dan hududu Allah (ketentuan dari Allah).

Namun demikian, sebagian fuqaha berpendapat bahwa pembagian warisan sebenarnya terletak pada prinsip an taradin (saling merelakan). Hal ini bermakna berbagai ketentuan yang rinci, pasti, dan tegas (qathy) atas maslah pembagian warisan tidak harus diterapkan secara kaku seperti bunyi ayatnya. Oleh karena itu, pembagian waris sangat tergantung pada kesepakatan atau kerelaan di antara para ahli waris yang sama-sama memperoleh harta warisan. Ketentuan pemabagian waris yang qathy tersebut baru diterapakan ketika ada sengketa atau tidak ada kesepakatan. ${ }^{24}$

Atas dasar adanya hubungan darah atau garis keturunan, maka anak sah mempunyai anak waris atas harta warisan ayah ibunya. Bagian yang berhak diterima oleh anak adalah sebagai berikut :

1. Apabila ahli waris hanya satu orang anak lelaki, maka ia akan memperoleh semua harta warisan ayah ibunya;

2. Apabila ahli waris terdiri dari dua anak lelaki atau lebih, maka harta warisan dibagi sama besar;

3. Apabila ahli waris hanya satu orang anak perempuan, maka ia mendapatkan $1 / 2$ bagian;

4. Apabila ahli waris terdiri dari dua anak perempuan atau lebih, maka masingmasing mendapatkan 2/3 bagian;

5. Apabila ahli waris adalah anak perempuan bersama-sama anak lelaki, maka bagian anak lelaki adalah dua berbanding satu dengan bagian anak perempuan $(2: 1)^{25}$.

Memperhatikan ketentuan bagian warisan bagi anak lelaki dan perempuan seperti itu, maka nampak jelas bahwa secara matematis bagian anak lelaki lebih banyak jika dibandingkan dengan anak perempuan. Namin ini bukan berarti hukum waris Islam bersifat patrilineal : hukum ini lebih dominan bersifat bilateral individual di mana ahli waris dapat menerima hak waris dari kedua sisi, baik kerabat ayah maupun ibunya. Di samping itu, harta warisan

24 A Qodri AZIZY, 2002, Eklektisisme Hukum Nasional Kompetesi antara Hukum Islam dan Hukum Umum, Gama Media, Yogyakarta, hlm.8.

${ }^{25}$ Titik Triwulan Tutik, Op.Cit, hlm. 323-324. 
pewaris dapat dimiliki secara perorangan, bukan dimiliki secara kolektif.

Kedudukan anak laki-laki dan perempuan dalam masyarakat Jawa adalah sebagai ahli waris yang berhak atas harta warisan dari orang tuanya. Dalam hal ini, anak lelaki maupun perempuan sama haknya untuk mewarisi harta warisan tetapi tidak berarti jumlah harta dibagi merata di antara para ahli waris. Cara pembagian harta waris tergantung pada keadaan harta dan ahli waris dan diupayakan untuk dijalankan secara rukun dan bersifat kebersamaan melalui musyawarah mufakat. Pada masyarakat Jawa, bagian anak lelaki dan perempuan sama haknya untuk mewarisi tetapi tidak masalah jika bagian anak lelaki dan perempuan berbeda.

Di berbagai daerah di kalangan masyarakat Jawa, dapat dikatakan ada dua kemungkinan pembagian warisan anatara anak lelaki dan anak perempuan, yaitu:

1. Cara dundum kupat atau sigar semangka, artinya bagian anak lelaki dan anak perempuan berimbang sama;

2. Cara segendong sepikul, artinya bagian anak lelaki dua kali lipat bagian anak perempuan. $^{26}$

Sebagaimana dikemukakan di muka, pada dasarnya semua anak dalam hukum adat Jawa, baik lelaki maupu perempuan, mempunyai hak yang sama atas harta warisan orang tuanya. Hak sama mengandung pengertian semua anak berhak untuk diperlukan sama. Oleh karena itu, atas dasar kerukunan dengan memperhatikan keadaan masing-masing ahli waris, bagian anak lelaki maupun anak perempuan adalah

\footnotetext{
${ }^{26}$ Hilman Hadikusuma, Op.Cit, hlm. 106.
}

sama. $^{27}$ Di sisi lain, jika anak lelaki mendapat dua kali bagiannya anak perempuan juga tidak masalah asal pembagian yang seperti ini didasarkan pada prinsip kepatutan. Prinsip menjaga harmoni atau menghindari pertikaian yang diakibatkan oleh pembagian warisan umumnya masih dianut sebagian orang Jawa. Ungakapan mangan ora mangan waton kumpul merupakan sarana ke arah persatuan. Karena suatu keluarga diharapkan tetap bersatu dalam keadaan apapun baik suka maupun duka ${ }^{28}$.

Pembedaan laki-laki dan perempuan tampak semakin jelas ketka orang Jawa melakukan pemabagian waris dengan cara segendong sepikul atau sapikul sagendhongan dengan ketentuan pria mendapat sapikul dan wanita sagendhongan. Hal ini menggambarkan sikap orang Jawa yang meninggikan pria dibandingkan wanita. Pria harus mendapatkan bagian yang lebih dalam segala hal, termasuk warisan. Pria dianologikan sebagai orang yang hebat, sakti dan istimewa dibanding wanita. Itulah sebabnya pria Jawa memiliki tugas dan tanggungjawab lebih dibandingkan wanita. Pria harus melaksanakan lima A, yaitu angayani (memberi nafkah lahir batin), angomahi (membuat rumah sebagai tempat tinggal), angayomi (pengayom dan pembimbing keluarga), angayemi (menjaga

\footnotetext{
${ }^{27}$ R. Soepomo, 1993, Bab-Bab tentang Hukum Adat, PT. Pradnya Paramita, Jakarta, hlm. 80.

28 Atik Triratnawati, 2006, "Hukum Agama, Hukum Barat, dan Adat. Kasus-Kasus Pewarisan di Yogyakarta”, dalam Heddy Shri Ahimsa Putra, eseiesei Antropologi Teori, Metodelogi dan etnografi, Kepel Press, Yogyakarta, hlm. 162.
} 
ketentraman keluarga), angamatjani (mampu menurunkan keturunan) ${ }^{29}$.

Memperhatikan perspektif hukum Islam dan hukum adat Jawa mengenai kewarisan, ternyata terdapat kesamaan di antara keduanya dalam hal hak waris anak lelaki dua kali lebih besar daripada anak perempuan, sedangkan dalam hukum adat Jawa pemabagia waris seperti dalam hukum Islam sangat dimungkinkan dengan menerapkan prinsip sapikul sagendhongan. Namun, selain sapikul sagendhongan hukum adat mengenal pula pembagian waris secara sigar semangka. Hal ini menunjukkan bahwa hukum adat dapat dikatakan lebih adaptif terhadap situasi dan kondisi para ahli waris jika dibandingkan dengan prinsip dalam hukum Islam.

\section{Aspek Ontologi Pembagian Waris dalam Hukum Islam dan Adat Jawa}

Dalam upaya memahami dinamika berbagai persoalan kehidupan manusia, kajian hukum yang lebih luas dan dalam pada akhirnya akan menemui kebuntuan karena ilmu hukum tidak mampu memberi solusi dengan memuaskan. Ketidakmampuan ini disebabkan oleh cepatnya perubahan nilai-nilai yang tidak mampu dijawab secara tuntas dan memuaskan oleh ilmu hukum. Menurut Rasjidi, jawaban ilmu hukum atas perubahan nilai-nilai tersebut hanya bersifat sepihak, tidak holistik, dan hanyalah berdasarkan panca indra belaka alih-alih mencoba melihat yang tidak dapat dilihat dan tersembunyi. Oleh karena itu, jawaban terhadap persoalan kehidupan hanya terbatas

\footnotetext{
${ }^{29}$ Suwardi Endaraswara, Op.Cit, hlm. 53-54.
}

pada perbauatan manusia dan tidak mencapai taraf pertimbangan nilai atas kebiasaan hukum manusia ${ }^{30}$. Persoalanpersoalan mendasar yang tidak dapat dijawab oleh ilmu hukum menjadi obyek bahasan ilmu filsafat. Menurut Anshori, filsafat mempunyai obyek berupa segala sesuatu yang dapat dijangkau oleh pikiran manusia $^{31}$. Oleh karenanya kajian filsafat seharusnya bisa menembus sesuatu di balik fakta, tidak hanya sebatas data empirik.

Filsafat atau ilmu filsafat mempunyai beberapa cabang ilmu utama, yaitu ontologi atau metafisika, epistimologi, dan aksiologi. Epistomologi membahas pengatahuan yang diperoleh manusia, sedangkan aksiologi membahas hakikat nilai sesuatu. ${ }^{32}$ Ontologi atau teori hakikat merupakan salah satu cabang filsafat yang paling kuno. Kata ontologi berasal dar Yunani, (on=being dan $\log o s=\operatorname{logic}$ ). Jadi ontologi adalah the theory of being qua being (teori tentang keberadaan sebagai keberadaan), sehingga ontologi itu mencari ultimate reality. ${ }^{33}$ Dalam persoalan ontologi, orang menghadapi persoalan bagaimana menerangkan hakikat dari segala yang ada. Pembicaraan tentang hakikat sngatlah luas karena meliputi segala yang ada dan yang mungkin ada. Sebagai contoh, hakikat makna demokrasi adalah menghargai pendapat rakyat, bukan tindakan sewenang-wenang pemerintah atau

${ }^{30}$ Lili Rasjadi dan Ira Thania Rasjidi, 2007, DasarDasar Filsafat dan Teori Hukum, PT. Citra Aditya Baku, Bandung, hlm. 3.

31 Abdul Ghofur Anshori, 2005, Filsafat Hukum Kewarisan Islam Konsep Kewarisan Bilateral Hazarin, UII press. Yogyakarta, hlm. 4.

32 Abdul Ghofur Anshori, 2006, Filsafat Hukum, Gajah Mada University Press. Yogyakarta, hlm. 1.

33 Amsal Bakhtiar, 2007, Filsafat Ilmu. PT. RajaGRafindo Persada, Jakarta, hlm. 132. 
demontrasi yang marak di masyarakat ${ }^{34}$. Dengan demikian, pembahasan ontologi sebagai dasar ilmu berusaha untuk menjawab apa hakikat sesuatu. Hakikat adalah realitas atau kenyataan yang sebenarnya atas sesuatu bukan keadaan yang menipu dan keadaan yang berubah ${ }^{35}$.

Berdasarkan pengertian sebagaimana diuraikan diatas, maka kajian masalah kewarisan dalam Islam dan adat yang sangat terbatas ini difokuskan pada aspek ontologi. Aspek ontologi ditekankan karena tulisan ini akan mengkaji secara filosofis persoalanpersoalan dalam hukum warisan, yaitu masalah harta warisan, saat pewarisan, ahli waris, dan bagian anak.

\section{Harta Warisan}

Cara pembagian harta warisan menurut Islam dapat dikatakan mudah sebab seluruh harta warisan berwujud segala sesuatu yang dapat dibagi, ditaksir, atau dinilai dengan uang. Sementara itu dalam hukum adat Jawa, harta warisan bisa lebih kompleks sebab ada beberapa jenis harta yang sifatnya immaterial berupa pangkat atau jabatan. Beberapa harta warisan bukanlah berwujud barang atau uang. Jawa menekankan kepada segala sesuatu yang tidak hanya bersifat empirik, melainkan lebih dari itu. Inilah perbedaan khas adat Jawa dengan Islam.

Jawa menganggap harta sebagai sampiran hidup, artinya harta memang harus dicari akan tetapi tidak perlu ngaya lan ngangsa, yang lebih penting adalah harmoni dalam pencarian maupun penggunaannya.

\footnotetext{
${ }^{34}$ Ibid, hlm. 131.

${ }^{35}$ Ahmad Tafsir, 2009, Filsafat Umum Akal dan Sejak Thales Sampai Capra, PT. Remaja Rosdakarya, Bandung, hlm.28.
}

Bagi orang Jawa, yang diutamakan adalah kerukunan dan kebersamaan sebagaimana pepatah Jawa mengatakan mangan ora mangan nek kumpul (biar tidak makan, asal bisa bersama), dan woten sekedhik dipundum sekedhik, woten kathah dipundum kathah (ada sedikit dibagi sedikit ada banyak dibagi banyak) ${ }^{36}$.

Sementara itu, Islam memandang harta sebagai jalan menuju ketakwaan. Islam menghendaki umatnya untuk bekerja keras sehingga etika Islam dalam perdagangan banyak dianut oleh wiraswasta Muslim. Selain itu, Islam menghendaki pendistribusian harta secara merata. Itulah sebabnya Islam memiliki lembaga zakat mal, infak, dan sedekah baik dalam lingkungan keluarga maupun luar keluarga seperti hibah, wasiat, atau wakaf. Semua itu bermuara pada pandangan bahwa harta tidak hanya diperuntukan bagi keturunan tetapi bagi umat manusia secara luas. Ini menyiratkan nilai bahwa menurut Islam kemanfaatan harta secar luas lebih utama (misalnya harta untuk jihad) dari pada sekedar peninggalan harta untuk anak keturunan. Islam memandang bahwa harta juga mampu memanjangkan amal seseorang. Oleh karena itu, sebuah hadis yang diriwayatkan oleh Muslim menyatakan bahwa ada tiga hal yang akan memperpanjang amalan seseorang, yaitu ilmu yang bermanfaat, do'a anak sholeh, serta sedekah jariyah ${ }^{37}$.

Sebaliknya, adat Jawa cenderung menekankan bahwa harta hanya

\footnotetext{
36 Koentjaraningrat, 1984, Kebudayaan Jawa, PN Balai Pustaka, Jakarta, hlm.441.

37 Imam Nawawi, 1999, Rivadhus Shalihin jilid 2 (terjemahan), Pustaka Amani, Jakarta, hlm.89.
} 
dimanfaatkan untuk anak keturunan saja, bahkan hanya sebatas keluarga inti (nuclear family) tidak meluas seperti halnya Islam yaitu sampai ke janda atau duda, orang tua (extended family), serta umat. Ini membawa pesan bahwa adat Jawa memang menghitung garis keturunan hanya pada skala kecil, sementara Islam mengaitkan keturunan dalam skala yang lebih luas. Bagi orang Jawa, memikirkan anak keturunan sendiri saja adalah hal yang paling penting. Kerabat di luar keluarga ini bukan menjadi tanggungan seseorang untuk membagi hartnya. Adapun Islam tidak hanya menekankan pada nasab tetapi juga hubungan perkawinan atau bahkan keagamaan.

Adat Jawa yang membagi harta immaterial brupa gelar, pangkat, atau jabatan seperti yang ditemukan di kalangan para priyayi atau bangsawan keraton membawa pesan bahwa pewaris harta harus menjaga dan memelihara budaya Jawa agar tetap lestari. Kewajiban bagi para penerima harta immaterial adalah menjaga supaya apa yang diwariskan itu dijaga kelestariannya. Menjaga harta immaterial lebih berat dari pada harta material karena diperlukan kesabaran dan ketelitian. Selain itu, harta immaterial tidak bisa dengan mudah diperjualbelikan karena tidak mudah dinilai dengan uang, melainkan lebih bernilai prestise. Dengan kata lain, warisan harta immaterial merupakan harta yang lebih cenderung bernilai budaya dan bukan ekonomis.

\section{Saat Pewarisan}

Ada perbedaan yan nyata antara saat pewarisan menurut adat Jawa dan Islam.
Dalam adat Jawa, ada kebiasaan untuk menunda pembagian waris sampai saat yang tepat, yaitu pada saat upacara selamatan kematian, baik 40 hari, 100 hari, 1 tahun, 2 tahun atau 1000 hari sejak kematian. Pada saat upacara penguburan, pembagian waisan belum dilakukan karena keluarga masih menganggap masa itu sebagai masa berkabung dan kesedihan masih dirasakan. Orang Jawa akan menganggap saru atau tidak pantas/patut apabila setalah upacara penguburan dilakuakn pembagian waris.

Penundaan pembagian waris ini memiliki sisi positif dan negatif. Sisi positif antara lain ahli waris mungkin tidak lagi berminat menerima warisan. Sementara sisi negatifnya adalah semakin kompleksnya keadaan sehingga ahli waris yang telah lama menunggu warusan itu dapat membuat intrik-intrik atau ada keinginan menguasai harta warisan yang tidak menjadi haknya. Mengingat orang Jawa sebelum seseorang meninggal jua mengenal kebiasaan memberi warisan baik lewat acungan, garisan, atau lintiran $^{38}$.maka penundaan pembagian waris dianggap wajar sebab masing-masing ahli waris sebenarnya dapat menerima bagian sebelum seseorang pewaris meninggal.

Sebaliknya dalam Islam pembagian waris akan dilakukan sesegera mungkin setelah upacara penguburan. Biasanya malam hari pasca penguburan keluarga akan memanggil pemuka agama untuk menyaksikan serta memberi arahan bagaimana waris dibagi secara Islam. Manfaat menyegerakan pembagian waris adalah demi menghindari konflik. Artinya masing-masing ahli waris tidak sempat

\footnotetext{
${ }^{38}$ Hilman Adikusuma, Op.Cit, hlm.78-79.
} 
membuat intrik atau siasat untuk menguasai harta. Pada saat pembagian waris harta si pewaris akan dikurangi dahulu dengan segala hutang-hutangnya setelah bersih barulah harta itu dibagi.

Islam adalah agama yang bersifat transparan dan akuntabel dalam masalah harta. Hal ini terbukti adanya perintah untuk membagi waris secepat mungkin setelah upacara penguburan. Semua hak yang menyangkut hak anak Adam akan segera dibereskan agar keluarga mengatahui seberapa besar harta maupun hutang si pewaris. Semakin cepat harta dibagi semakin baik nilainya, hal ini dikarenakan adanya ketentuan bahwa harta yang bermasalah akan mempersulit si mati di dalam kubur. Jika harta yang ditinggalkan ahli waris segera dibagi menurut aturan syara',maka si mati akan terbebas dari masalah pertanyaan kubur menyangkut harta benda.

Adat Jawa, sebaliknya, cenderung bersikap perlahan-lahan atau dengan kata lain suka menunda-nunda (alon-alon waton kelakon gremet-gremet waton slamet), termasuk dalam pembagian waris. Hal ini juga diilhami oleh paham Jawa bahwa membicarakan uang atau harta adalah hal yang saru (tabu). Bahkan dalam kehidupan sehari-hari pun masalah uang biasanya akan ditutup-tutupi oleh orang Jawa. Berbicara masalah uang,apalagi secara langsung, dianggap saru, ditambah lagi dianggap tidak pantas jika suasana duka yang masih menyelimuti keluarga disisipi oleh acara menghitung uang atau membagi harta waris. Oleh karena itu, bagi orang Jawa, lebih ideal untuk mengendalikan diri dalam hal membicarakan masalah kewarisan sehingga mampu menjalankan madu basa (berbicara sopan), madu rasa, (tenggang rasa, empati), dan madu brata (adatif-responsif tetapi masih terkait aspek ilahiyah) ${ }^{39}$.

\section{Ahli Waris}

Nasab adalah salah satu hal yang sangat penting di dalam agama Islam. Bahkan, hubungan dalam sebuah keluarga besar juga memiliki arti yang cukup berarti dalam kekerabatan Islam. Islam mengenal pranata extended family sehingga penelusuran kerabat seperti bani (anak keturunan) cukup relevan dengan pentingnya arti keluarga besar. Penanaman seseorang dengan tambahan kata bin atau binti yang artinya anak lelaki atau anak perempuan dari seseorang menjadi penanda bahwa nama orang tua adalah suatu hal yang penting, melihat nasab seseorang ditelusuri dari garis bapaknya. Sebaliknya dalam kekerabatan Jawa biasanya orang hanya memeliki nama diri tanpa nama bapak atau keluarga. Sistem kekerabatan parental Jawa mengindikasikan bahwa kekerabatan bapak dan ibu samasama penting sehingga demi rasa keadilan maka seseorang cukup diberikan nama diri. Lagipula, jika nama bapak atau ibu disertakan, maka nama itu akan menjadi semakin panjang.

Islam mengenal jumlah golongan ahli waris yang cukup luas sebab ahli waris tidak terbatas hanya pada anak-anak melainkan meluas ke istri, orangtua, dan saudara kandung. Hukum adat Jawa lebih sederhana sebab harta hanya diwariskan ke tingkat anak saja. Hak waris istri atau orangtua dan saudara gugur karena telah tertutup oleh ahli

39 Hemy Astiyanto,2006, Falsafah Jawa Menggali Butir-butir Kearifan Lokal, Warta Pustaka, hlm.367. 
waris pertama dan utama (anak), sebagai akibatnya. Keseluruhan harta akan jatuh hanya kepada anak. Adanya perbedaan prinsip ahli waris yang meluas dalam Islam dan menyempit untuk adat Jawa ini dikarenakan Islam menghendaki harta agar dapat terdistribusi secara merata tidak hanya diantara keluarga yang se-nasab tetapi juga di antara keluarg yang ikatannya timbul akibat tali perkawinan atau agama. Nilai sosialitas Islam selalu menyebar secara luas sehingga pemanfaatan harta warisan bisa sangat luas, meskipun kemudian harta terbagi-bagi sampai jumlah yang kecil. Sebaliknya, adat cenderung menginginkan harta supaya terpusat hanya pada anak keturunan langsung agar pemanfaatannya lebih bisa dirasakan pada keluarga yang mempunyai hubungan nasab. Dengan demikian, tidak peduli jumlah harta yang dikumpulkan oleh pewaris besar atau kecil, harta tersebut hanya boleh dinikmati oleh keturunan lansung, bukan yang lainnya.

Implikasi logis dari adanya ahli waris yamg meluas dan menyempit adalah terkait dengan etos kerja yang diilhami semangat etika Islam, bahwa umat Islam harus bekerja keras seakan-akan hidup masih 1000 tahun lagi dan beribadah sekuat-kuatnya seakanakan besok pagi akan mati. Akibatnya, menjadi wirausaha atau pedagang sangat disukai dalam Islam sebab pedagang akan mengumpulkan harta sebanyak-banyaknya agar warisan untuk kerabat juga banyak. Akan tetapi di sisi lain, di dalam masyarakat Jawa hidup etika sakmadya (secukupnya) yang membatasi ruang gerak masyarakat: mencari harta itu tidak perlu ngaya tapi cukup sedang-sedang saja karena harta tidak akan dibawa mati dan harta hanya untuk anak-anak saja. Kehidupan orang Jawa yang mayoritas petani tidak kemungkinkan seseorang untuk menjadi konglomerat sebab kehidupan ekonominya menganut ekonomi subsisten.

\section{Bagian Anak}

Makna yang selalu terdapat di dalam setiap fenomena berperan sebagai penuntun dan pegangan filosofi hidup masyarakat yang bersangkutan. Kita dapat menarik makna filosofis dari hukum kewarisan dengan menganalisis cara masyarakat membagi harta warisannya.

Setiap fenomena selalu mengandung makna tertentu yang diberikan oleh masyarakat yang mempraktikannya. Seringkali, fenomena masyarakat ini berperan sebagai penuntun atau filosofi hidup. Hukum kewarisan Islam, sebagai contoh, memiliki filosofi yang dlaam hal pembagian waris. Aturan pembagian waris dua berbanding satu untuk anak perempuan terhadap anak lelaki merefleksikan tanggungjawab lelaki yang dua kali lebih besar dari pada perempuan, mengingat lelaki wajib menanggung istri dan anak-anaknya, pembagian waris yang dua kali lebih besar dibanding perempuan ini pada akhirnya tidak akan seorang lelaki menikmati untuk dirinya sendiri, melainkan akan disalurkan kembali untuk istri dan anak-anak yang menjadi tanggung jawabnya. Di sisi lain, perempuan hanya mendapatkan suatu bagian sebab ia tidak menanggung siapa-siapa kecuali dirinya-sendiri. Apabila seorang perempuan telah bersuami, maka kehidupan perempuan telah bersuami, maka kehidupan perempuan itu akan menjadi tanggungan suaminya. Dengan demikian, satu bagian 
yang perempuan terima pada akhirnya akan ia nikmati untuk diri pribadinya sendiri, justru, seorang perempuan akan merasa beruntung sebab selain ia mendapat satu bagian dari warisan orang tuanya apabila orang tuanya apabila orang tuanya meninggal, suaminya akan mendapat dua bagian harta warisan sehingga apabila digabungkan, satu keluarga akan mendapatkan tiga bagian harta warisan. Jumlah ini tentu terasa adil karena tanggungjawab lelaki dalam Islam sangat korelatif dengan bagian hak warisnya. Dalam kaitan masalah ini, sebagian fuqaha secara tegas menyatakan bahwa hukum kewarisan seharusnya diterima secara ta'abuddy atau taken for granted. Konsekuensinya, segala sesuatu yang diatur dalam Alquran harus diterima dengan senang hati sebagai bukti kepatuhan kepada Allah $^{40}$.

Dalam literaturnya, Muhammad Syah menegaskan bahwa Islam memberikan bagian waris lebih banak kepada perempuan karena lelaki mempunyai tanggungjawab atau kewajiban lebih berat. Lelaki berkewajiban memberikan nafkah terhadap keluarga, isteri dan anak. Di samping itu, dikarenakan sifat kelaki-lakian melebihi sifat kewanitaan dalam fisik maupun psikis, lelaki dianggap sebagai pemimpin bagi wanita $^{41}$.

Sementara itu, terdapat dua cara pembagian waris bagi anak dalam masyarakat Jawa, yaitu sistem pembagian sigar semangka dan sagendhong sepikul.

\footnotetext{
${ }^{40}$ Ahmad Rofiq,2000, Hukum Islam di Indonesia, PT. Raja Grafindo Persada, Jakarta, hlm.374.

${ }^{41}$ Ismail Muhammad Syah, dkk, 1999, Filsafat Hukum Islam. Bumi Aksara - Direktorat Jenderal Pembinaan Kelembagaan Agama Islam, hlm.39.
}

Pembagian waris sigar semangka memberikan hak yang sama bagi laki-laki dan perempuan karena diasumsikan keduanya sama-sama akan membangun keluarga yang memerlukan banyak modal. Bagian yang sama besarnya ini dimaksudkan sebagai modal berumahtangga. Sistem pembagian ini terasa adil sebab baik istri maupun suami sama-sama menyumbang bagi ekonomi keluarga sehingga istri tidak lagi ditanggung oleh suami; ia bisa ikut membagun ekonomi keluarganya sendiri.

Situasi ekonomi keluarga inti Jawa yang umumnya serba kekurangan akan tertolong dengan model pembagian sigar semangka ini. Pada umumnya model sigar semangka diambil sebagai dasar kebijakan pembagian waris suatu keluarga setelah diamati bahwa anak-anaknya, baik laki-laki maupun perempuan, belum cukup mampu untuk mandiri secara ekonomi. Dengan demikian, esensi dari pembagian sigar semangkaadalah adanya kesinambungan keturunan agar dapat bertahan menopang keperluan hidup suatu rumah tangga.

Adapun sistem pembagian segendhong sepikul mengamanatkan agar ahli waris anak lelaki mendapatkan bagian harta warisan dua kali lipat dari bagian anak perempuan. Hal ini dilatarbelakangi asumsi bahwa lelaki mempunyai tanggungjawab yang lebih besar jika dibandingkan dengan wanita. Dengan begitu sudah semestinya jika anak lelaki diberikan hak waris yang lebih banyak jika dibandingkan dengan anak perempuan. Lelaki yang menjadi kepala keluarga akan memiliki tanggungjawab untuk memenuhi keperluan istri dan anakanaknya, sedangkan perempuan tidak ada kewajiban untuk mencukupi kebutuhan 
suami dan anak-anaknya. Apabila istri ikut membantu mencukupi keperluan keluarga tersebut, maka hal ini dianggap sebagai kebaikan istri belaka.

\section{Penutup}

Berdasarkan uraian pembahasan di atas, maka dapatlah dikemukakan rumusan kesimpulan sebagai berikut:

1. Pada dasarnya terdapat kesamaan dalam hukum Islam dan hukum adat Jawa di bidang jenis harta warisan. Harta yang berhak diwarisi oleh para ahli waris hanyalah harta yang berstatus sebagai harta warisan, bukan harta peninggalan atau harta perkawinan. Dalam hukum Islam, seluruh harta yang diwariskan dapat dituntut sebagai pelunasan utang, sedangkan dalam hukum adat Jawa, harta yang dapat digunakan untuk melunasi utang hanyalah jenis harta bersama atau harta gana gini dan harta bawaan yang berhutang. Dalam hukum Islam, saat pewarisan akan terbuka dan pembagian harta baru dapat dilangsungkan pada saat pewarisan akan terbuka dan pembagian harta baru dapat dilangsungkan pada saat si pewaris wafat. Hukum adat Jawa tidak menganut prinsip yang sama: menurut hukum adat, saat pewarisan dapat terjadi saat pewaris masih hidup ataupun setelah pewaris wafat. Ahli waris menurut Islam digolongkan menjadi tiga, yaitu ahli waris dzawil furudl, ashabah, dan dzawil arham. Selain itu, ahli waris pada pula digolongkan menjadi ahli waris nasabiyah dan sabbiyah. Adapun hukum adat Jawa menempatkan anak sebagai ahli waris yang utama dan pertama. Setelah anak, ahli waris yang kakek-nenek pewaris. Terdapat prinsip saling menutupi antara para ahli waris yang lain. Dalam hukum kewarisan Islam, anak lelaki mendapat bagian harta warisan sebanyak dua kali bagian anak perempuan. Namun, jika ada 'an taradin diantara ahli waris, maka pembagian harta warisan untuk anak lelaki dan perempuan dapat didasarkan pada kesepakatan bersama. Apdapun dalam hukum adat Jawa, terdapat dua sistem pembagian waris untuk anak, yaitu sistem sigar semangka (satu banding satu) dan sistem segendhong sepikul (dua banding satu).

2. Dalam Islam, harta memiliki makna filosofis secara ontologi sebagai sarana beramal atau ibadah. Dengan demikian, harta warisan diperuntukkan baik bagi kalangan keluarga maupun umat sekitar. Akan tetapi menurut hukum adat Jawa, harta diutamakan sebagai bekal material bagi kehidupan keluarga terdekat saja. Pada prinsipnya hukum kewarisan Islam menghendaki pembagian waris yang dilakukan segera setelah wafatnya pewaris. Tidak demikian halnya dengan hukum adat Jawa yang cenderung menggantungkan saat pembagian kepada situasi dan kondisi tertentu. Apabila para ahli waris memerlukan bekal hidup saat pewaris masih hidup. Maka proses pewarisan dilakukan ketika pewaris masih hidup, maka pewarisan akan dijalankan setelah Islam, seseorang dapat menjadi ahli waris yang berhak mendapatkan harta warisan apabila memiliki hubungan 
Jurnal Unifikasi, ISSN 2354-5976

Vol. 3 No. 2 Juli 2016

nasab, perkawinan atau keagamaan. Hal ini mengindikasikan bahwa nilai sosial menurut Islam menyebar luas sampai ke luar keluarga inti. Dalam hukum adat, yang berhak sebagai ahli waris terbatas pada keluarga dekat. Dengan demikian, hukum adat mengisyaratkan adanya nilai sosial terbatas jika dibandingkan hukum Islam. Hak waris anak lelaki dalam Islam adalah dua kali bagian anak perempuan karena dianggap beban tanggungjawab lelaki terhadap keluarga lebih berat jika dibandingkan dengan perempuan. Adapun bagian anak lelaki dan perempuan di kalangan masyarakat Jawa sangat tergantung kepada kondisi para ahli waris. Apabila kondisi ahli waris dipandang mampu mengakomodasi pembagian harta warisan yang setara jumlahnya antara anak lelaki dengan perempuan, maka dipilih model sigar semangka. Namun, jika dipandang lebih layak apabila ahli waris anak menerima harta yang dibagi melalui perbandingan dua berbanding satu, maka akan dijalankan sistem segendhong sepikul.

\section{DAFTAR PUSTAKA}

Ali, Zainuddin, 2008, Pelaksanaan Hukum Waris di Indonesia, Sinar Grafika, Jakarta.

Anshori, Abdul Ghofur dan Yulkanain Harahab,2008, Hukum Islam Dinamika dan Perkembangannya di Indonesia, Kreasi Total Modal Media, Yogyakarta.

Anshori, Abdul Ghofur, 2002, Hukum Kewarisan Islam di Indonesia Eksistensi dan Adaptabilitas, Ekonesia Fakultas Ekonomi UII, Yogyakarta. , 2005, Filsafat Hukum Kewarisan Islam Konsep Kewarisan Bilateral Hazairin, UII Press. Yogyakarta. 2006, Filsafat Hukum, Gadjah Mada University Press. Yogyakarta.

Arto, Mukti, 2009, Hukum Waris Billateral dalam Komplikasi Hukum Islam, Balqis Queen, Solo.

Astiyanto, Heniy, 2006, Filsafat Jawa Menggali Butir-Butir Kearifan Lokal, Warta Pustaka.

Azizy, A Qodri Azizy, 2002, Eklektisisme Hukum Nasional: Kompetisi antara Hukum Islam dan Hukum Umum, Gama Media, Yogyakarta.

Bakhtiar, Amsal, 2007, Filsafat Ilmu, PT. Raja Grafindo Persada, Jakarta.

Basyir, Ahmad Azhar, 1982, Hukum Waris Islam, Fakultas Ekonomi UII, Yogyakarta.

Endaswara, Suwardi, 2006, Falsafah Hidup Jawa, Cakrawala, Yogyakarta. 2006, Mistik Kejawean Sinkritisme, Simbolisme dan Sufisme dalam Budaya spritual Jawa, Narasi, Yogyakarta.

Hamid, Syamsul Rijal, 2000, Buku Pintar Agama Islam, Penerbar Salam, Jakarta.

Hilman Hadikusuma, 1999, Hukum Waris Adat, PT.Citra Aditya Bakti, Bandung.

Imam Nawawi, 1999, Riyadhus Shalihin Jilid 2 (Terjemahan), Pustaka Amani, Jakarta. 
Jurnal Unifikasi, ISSN 2354-5976

Vol. 3 No. 2 Juli 2016

Koentjaraningrat, 1984, Kebudayaan Jawa, PN Balai Pustaka, Jakarta.

Kusumaatmadja Mochtar, 1975, Pembinaan Hukum dalam Rangka Pembagunan Nasional, BinaCipta, Bandung.

Lukito, Ratno, 2008, Tradisi Hukum Indonesia, Teras, Yogyakarta.

Mulder, Niels, 2001, Mistisisme Jawa Ideologi di Indonesia, LkiS, Yogyakarta.

Rasjadi, Lili dan Ira Thania Rasjidi, 2007, Dasar-Dasar Filsafah dan Teori Hukum, PT Citra Aditya Bakti, Bandung.

Rato, Dominikus, 2009, Pengantar Hukum Adat, LaksBang Pressindo, Yogyakarta.

Rofiq, Ahmad, 2000, Hukum Islam di Indonesia, PT. Raja Grafindo Persada, Jakarta.

S.Tamakiran, 2000, Asas-asas Hukum Waris Menurut Tiga Sistem Hukum, Pionir Jaya, Bandung.

Salman, R Otje dan Mustofa Haffas, 2006, Hukum Waris Islam, PT. Refika Aditama, Bandung.

Salman, R Otje, 2007, Kesadaran Hukum Masyarakat terhadap hukum Waris, PT. Alumni, Bandung.

Sirajuddin, 2008, Legislasi Hukum Islam di Indonesia, Pustaka Pelajar, Yogyakarta.

Sirajuddin, Soerjono, 2001, Hukum Adat Indonesia, Raja Grafindo Persada, Jakarta.

Soepomo, R., 1993, Bab-bab tentang Hukum Adat, PT. Pradnya Paramita, Jakarta.

Sudaryanto, Agus, 2005, "Sepikul Segendong: Harmonisasi Hukum Adat dan Islam dalam Pewarisan terhadap Anak". Dalam Atik Triratnawati dan Mutiah Amini (Eds), Ekspresi Islam dalam Simbol-simbol Budaya di Indonesia, PT. Adicita, Yogyakarta.

Sudiyat, Iman, 1983, "Peta Hukum Waris di Indonesia”, Simposium Hukum Waris Nasional, Februari, Jakarta.

Suparman, Eman, Hukum Waris di Indonesia dalam Perspektif Islam, Adat dan BW, PT. Refika Aditama, Bandung.

Syah, Ismail Muhammad, 1999, Filsafat Hukum Islam, Jakarta, Bumi Aksara -Direktorat jenderal Pembinaan Kelembagaan Agama Islam, Departemen Agama.

Syaifuddin, Amir, 1984, Pelaksanaan Hukum Kewarisan Islam dalam Lingkungan Adat Minangkabau, PT. Gunung Agung, Jakarta.

Tafsir, Ahmad, 2009, Filsafat Umum Akaldan Hati Sejak Thales Sampai Cupra, PT. Remaja Rosdakarya, Bandung.

Triratnawati, Atik, 2006, "Hukum Agama, hukum Adat, dan Adat, Kasus-kasus Pewarisan di Yogyakarta", dalam Heddy Shri Ahimsa Putra (Ed.) Esei-esei Antropologi Teori, Metodologi, dan Etnografi, Kepel Press. Yogyakarta.

Tuitk, Titik Triwulan, 2006, Pengantar Hukum Perdata di Indonesia, Prestasi Pustaka Publiser, Jakarta. 